\title{
ESTUDO DO BIOCOMPÓSITO DE P3HB/NANODIAMANTE PARA APLICAÇ̃̃O EM DISPOSITIVOS MÉDICOS, PARTE 1: PROPRIEDADES MECÂNICAS E TÉRMICAS
}

\author{
Lucivan Pereira Barros Junior ${ }^{1 *}$, Príscila Pinheiro Pereira1, Yan Yucif Vieira Azevedo \\ Maia $^{1}$
}

\begin{abstract}
RESUMO
BARROS JR, L P.; PEREIRA, P. P.; MAIA, Y. Y. V. A. Estudo do biocompósito de $\mathrm{P} 3 \mathrm{HB} /$ nanodiamante para aplicação em dispositivos médicos, parte 1: propriedades mecânicas e térmicas. Perspectivas Online: Exatas \& Engenharia, v. 10, n. 29, p. 13-29, 2020.

Dispositivos médicos, principalmente implantes ortopédicos, existentes no mercado para aplicação de fixação óssea (titânio, aço inoxidável e etc.) apresentam limitações em relação à incompatibilidade de propriedades mecânicas do tecido ósseo, como módulo de elasticidade, propriedade esta que está relacionada com a quantidade de carregamento suportado pelo material em um solicitação mecânica. O objetivo deste trabalho foi a obtenção de um material compósito biodegradável e biocompatível de matriz polimérica de poli-hidroxibutirato $(\mathrm{P} 3 \mathrm{HB})$ reforçado com uma segunda fase de nanodiamantes (ND) através da técnica de evaporização de

utilizada para obtenção de compósitos, sob conhecimento dos autores, e sua caracterização térmica, mecânica, morfológica e in vitro. Como resultado da técnica de Spray-Dryer, partículas de diamantes encapsuladas pela matriz foram obtidas em diferentes concentrações de ND/P3HB. O objetivo principal deste trabalho é avaliar a eficiência da técnica de Spray-Dryer utilizada na dispersão da carga na matriz e em sua homogeneidade, refletindo nas propriedades mecânicas e térmicas do compósito, aplicando modelos mecânicos para esta avaliação. Análises de citotoxicidade in vitro serão discutidas na Parte 2 deste artigo.
\end{abstract} solvente Spray-Dryer, que nunca foi

Palavras-chave: Poli-3-hidroxibutirato; nanodiamantes; nanocompositos.

\footnotetext{
${ }^{1}$ Universidade Estadual do Norte Fluminense - UENF - Laboratório de Materiais Avançados LAMAV/CCT - Avenida Alberto Lamego, 2000, Parque Califórnia, Campos dos Goytacazes, RJ, CEP: 28013-602, Brasil.

(*) e-mail: 1pb24@case.edu
} 


\title{
STUDY OF P3HB/NANODIAMOND BIOCOMPOSITE FOR MEDICAL DEVICES APPLICATION, PART 1: MECHANICAL AND THERMAL PROPERTIES
}

\section{Lucivan Pereira Barros Junior ${ }^{*}$, Príscila Pinheiro Pereira1, Yan Yucif Vieira Azevedo Maia $^{1}$}

\begin{abstract}
BARROS JR, L P.; PEREIRA, P. P.; MAIA, Y. Y. V. A. Study of P3HB/nanodiamond biocomposite for medical devices application, part 1: mechanical and thermal properties. Perspectivas Online: Exatas \& Engenharia, v. 10 , n.29 , p. 13-29, 2020.

Medical devices, especially for orthopedic implants, available in the market for bone fracture fixation (titanium, stain steel etc.) present some limitation when it comes to the properties compatibility to the bone tissue, such as elastic modulus, which plays an important role in the amount of mechanical load that a material can hold. The goal of this work is to obtain a new biodegradable and biocompatible nanocomposite with polymer matrix of poly-hydroxybutyrate (P3HB) loaded with particles of nanodiamonds (ND). The nanocomposites were obtained by SprayDryer, a solvent vaporization technique for

group), and their mechanical, thermal and morphological properties were investigated. The result composite from the Spray Dryer technique were diamond particles capsuled with the polymer matrix in various composition. The main goal of the mechanical analysis is to evaluate the efficiency of the technique in the homogeneity and dispersion of the nanofiller in the polymer matrix by applying models that predict these characteristics in nanocomposites. In vitro analyses of the cytotoxicity for all the sample composition will be discussed in Part 2.
\end{abstract} the first time, to the author knowledge (a technique that is being patented by the

Keywords: Poly-3-hydroxybutyrate; nanodiamonds; nanocomposites.

\footnotetext{
${ }^{1}$ Northern State University Fluminense Darcy Ribeiro - UENF - Advanced Materials Laboratory LAMAV/CCT - Alberto Lamego Avenue, 2000, Parque Califórnia, Campos dos Goytacazes, RJ, CEP: 28013-602, Brasil.

(*) e-mail: 1pb24@case.edu 


\section{INTRODUCTION}

The big challenge faced by medical device industry is finding materials suitable to implants application, especially when it comes to orthopedic and dental use, for bone fracture fixation for example. This is due to the incompatibility between material properties and bone tissue properties (RAMAKRISHNA et al., 2001). Commercial materials, in their most availability, are made of metals, such as titanium and stain steel, or ceramic such as hydroxyapatite. Those materials have elastic modulus and resistance significantly higher than the same properties for the human bone, in the range between 100-200 GPa for the elastic modulus. This difference makes the material to support the most part of the mechanical load applied in the interface implant/bone, affecting the regeneration and healing process of the bone leading to its atrophy (SCHOLZ et al., 2011, ADAMS D; WILLIANS D F; HILL J, 1978; CHRISTEL P; CLAES L; BROWN S A, 1991).

Finding material with similar properties to the bone is the solution for this issue (RAMAKRISHNA et al., 2001, SCHOLZ et al., 2011). Composite materials with polymer matrix can provide relatively low modulus, compared with bone's modulus, and be tailored to provide high resistance through the addition of a second phase (SCHOLZ et al., 2011). Nowadays, there is a wide range of biodegradable and bio based polymers than has being used for medical devices, such as polylatic acid (PLA), which derives from the fermentation of sugar with lactic acid and polyhydroxyalkanoates (PHA), which is a class of polymers produced by microorganisms that use it as a carbon and energy reserve, leading to an even biocompatible material (SCHOLZ et al., 2011, FARUK et al., 2012; SILVA, 2007).

Poly-3-hydroxybutyrate (P3HB) and poly-hydroxyvalerate (PHBV) are polymers of the PHA class most researched for biomaterials (SILVA, 2007). Most notably, the P3HB that is obtained by means of a bacterium that when fed with excess carbon stores energy in the form of polyester (CARASCHI 2008). This great interest in P3HB is because it is an environmentally degradable polymer, and that despite being produced from renewable raw materials, they can be processed as conventional thermoplastics. In addition to the possibility of an infinite number of applications according to Holmes (1985). On the other side of this spectrum, it is the second phase or the load of the composite, which is responsible for the structural support of the mechanical load (FARUK, 2012).

The objective of developing a composite is to obtain a material with better properties, such as greater rigidity and tensile strength and temperature of thermal distortion, in addition to reducing costs. With the development of nanotechnology and nanoscience, it became possible to obtain these composites on a Nano metric scale - the nanocomposites. When a particle has at least one of its dimensions in the order of $10^{-9} \mathrm{~m}$, it is said to be Nano metric. In this way, the material of two phases is called nanocomposite where one of them - the charge is dispersed in the other - the matrix - at the Nano metric level.

Often polymeric matrices with mineral fillers are used. Authors have studied nanoclays, diamond in nano and microsized, bioactive glass ball, wood residue, hidroxiapatite to be used as a second phase in polymer matrix composite (BAKAR, 2013, CARASCHI, 2008, COELHO, 2003, ZHANG, 2011; LEILA, 2009). The use of nanofillers has been increased due to its capability to produce a better interaction between the implant and the new tissue that is going to be regenerating in the interface implant/bone (SATO, 2004). The interaction of the matrix with the load is more efficient, since the fact of working at the nanoscale makes the area of contact between them larger, improving the properties of

Persp. Online: exatas \& eng., Campos dos Goytacazes, 29 (10) $13-29-2020$ 
nanocomposites compared to composites (GARCIA, 2003).

The development of biocomposites and absorbable membranes which have advantages such as the absence of a second surgical act and the elimination of damage to newly formed tissues, as well as desirable mechanical properties are interest area for medical device and orthopedic implants industry. The incorporation of nanodiamond in polyhydroxyalkanoate (PHA) family obtained by Spray-Dryer technique was done for the first time by Barros Jr et al (BARROS JR, 2014), when poly-3-hydroxybutyrate (P3HB) was used as a matrix. Posteriorly, the same group of research used the co-polymer poly(3-hydroxybutyrate-co-3hydroxyvaleerate) (PHB-HV) to evaluate the mechanical properties of the composite (ALMEIDA NETO et al., 2017; BARCELOS et al., 2017; ALMEIDA NETO et al., 2019). This present work develops a methodology to produce a nanocomposite from the dissolution of $\mathrm{P} 3 \mathrm{HB}$ in chloroform and posterior addition of ND during mixing with the formation of microcapsules of nanodiamonds particles encapsulated by the $\mathrm{P} 3 \mathrm{HB}$ polymer matrix. This methodology aims to provide a better dispersion and distribution of the nanofiller in the polymer matrix loading to enhanced mechanical properties of the final material. The mechanical properties were investigated by flexural test and DMA (Dynamic mechanical analysis) and the morphology of the microcapsules and nanodiamonds were evaluated by SEM. In vitro analyses were performed for cytotoxicity evaluation and results will be discussed in Part 2 of this paper.

\section{Experiamental}

\subsection{Materials}

Poly-3-hydroxybutyrate (P3HB) with $\mathrm{M}_{\mathrm{W}}=600,00 \mathrm{D}, \mathrm{T}_{\mathrm{M}}=175{ }^{\circ} \mathrm{C}, \mathrm{T}_{\mathrm{g}}=5{ }^{\circ} \mathrm{C}$ and density between $1.20-1.24 \mathrm{~g} / \mathrm{m}^{3}$ supplied by PHB Industria, synthetic particle nanodiamonds (ND) with a diameter of $125 \mathrm{~nm}$ obtained by Diambra Diamates, Chloroform $(99,8 \%)$ and Ethyl alcohol purchased by Sigma-Aldrich.

For nanocompostites (denoted 1 to 4 ) containing 9/91, 12/88. 14/86 and 20/80 $(\mathrm{ND} / \mathrm{P} 3 \mathrm{HB}, \mathrm{w} / \mathrm{w})$, respectively, were prepared in order to vary the evaluate the effect of ND concentration in the composite properties.

\subsection{Nanocomposite preparation}

The P3HB used was purified using chloroform as a solvent in a solution of $10 \mathrm{~g}$ of $\mathrm{P} 3 \mathrm{HB}$ to $160 \mathrm{ml}$ of chloroform. In a round bottom flask, it was left under continuous stirring at $150 \mathrm{RPM}$ at room temperature. The polymer was purified at reflux for an average of 10 hours and, shortly thereafter, it was precipitated in a $95 \%$ ethyl alcohol solution at a temperature of approximately $0{ }^{\circ} \mathrm{C}$ under continuous stirring. The $\mathrm{P} 3 \mathrm{HB}$ solution precipitated in ethanol was left to stand for the precipitate to decant.

After the separation of $\mathrm{P} 3 \mathrm{HB}$ from ethyl alcohol, the polymer was taken to the oven to dry at $60{ }^{\circ} \mathrm{C}$ for 2 hours, for the partial elimination of solvents. The purified P3HB was stored in a vacuum desiccator. For the coating/encapsulation of the nanodiamond particles, in the $\mathrm{P} 3 \mathrm{HB}$ matrix, a solution of purified $\mathrm{P} 3 \mathrm{HB}$ in chloroform was prepared in the proportion of $4 \mathrm{~g}$ of $\mathrm{P} 3 \mathrm{HB}$ to $150 \mathrm{ml}$ of chloroform forming a homogeneous solution of $\mathrm{P} 3 \mathrm{HB}$ in chloroform. The nanodiamond particles were added to the solution, under stirring, in two different concentrations of P3HB-ND, the first being 4: 1 and the second 8: 1 . This

Persp. Online: exatas \& eng., Campos dos Goytacazes, 29 (10) $13-29-2020$ 
Chloroform-P3HB-ND solution was evaporated using the Spray-Dryer (B-191, Büchi) technique (subject to patent claim) which allowed the nanoparticles to be coated/encapsulated.

The encapsulation of the particles was conditioned by the conditions of the methodology used, obtaining different concentrations and coating for samples 1-4. For the preparation of the specimens for the mechanical flexure test, compression test and DMA thermal analysis, the $\mathrm{P} 3 \mathrm{HB} / \mathrm{ND}$ encapsulated were previously weighed and placed in the metal mold. The mold was taken to a vacuum vibration system for a period of 5 minutes so that the particles could be better accommodated within the mold matrix. The system was taken to the press and heated to $135^{\circ} \mathrm{C}$ with the aid of a uniform heating system. When stabilizing the temperature, a pressure of 8 Ton on the mold plunger was applied for the molding of the specimens. Rectangular and cylindrical specimens were made with dimensions of $5 \times 12 \times 35 \mathrm{~mm}$ and $12,7 \times 20 \mathrm{~mm}$, respectively, for flexure, DMA and compression tests.

\subsection{Nanodiamond characterization}

X-ray diffraction was used to determine the percentage of crystallinity in the polymer phase and the influence of the addition of ND particles on the crystallinity. Diffractograms were obtained using a Shimadzu XRD7000 diffractometer, available at UENF / CCT / LAMAV, equipped with X-rays of $\mathrm{Cu} \mathrm{K} \alpha(\lambda=0.1540 \mathrm{~nm})$. The scans were made in the diffraction angle range $2 \theta=2-40^{\circ}$ and speed of $0.5^{\circ} \mathrm{min}$.

The mechanical performance of the nanocomposites was tested under a flexion condition in the three-point system. The tests were carried out on the universal mechanical testing machine, brand Instron, model 5582. The values of flexion/elasticity module (E) and maximum stress $(\sigma \mathrm{M})$ have been determined. Using the test speed of $1.0 \mathrm{~mm} / \mathrm{min}$, the test conditions were in accordance with the ASTM D790 (2010) standard. The nanocomposite behavior under a uniaxial compression force were evaluates by compression test. To obtain these properties, a universal mechanical testing machine, brand Instron, model 5582, was used. Cylindrical specimens with dimensions of $12.7 \mathrm{~mm}$ in diameter and $25.4 \mathrm{~mm}$ in height and a test speed of $1.3 \mathrm{~mm} / \mathrm{min}$ were the test parameters according to ASTM D695 (2010). Vickers microhardness tests were carried out in conditions according to the technical standard ASTM E 384 (2011). The test was carried out in a micro-meter Shimadzu HMV-2 series with a load of $300 \mathrm{~g}$ (CHEN; WANG, 2002) and an indentation time of 20 seconds. Dynamicmechanical analysis was performed on a DMA Q800 TA instruments. A mini flexion claw at three points was used in a frequency of $1 \mathrm{HZ}$, amplitude of $10 \mu \mathrm{m}$ and static force of $0.1 \mathrm{~N}$. The samples were cooled to $25^{\circ} \mathrm{C}$, maintained isothermally at this temperature for 3 minutes and then heated at a rate of $3{ }^{\circ} \mathrm{C} / \mathrm{min}$ up to $190^{\circ} \mathrm{C}$. The storage (ES), loss (EL) and damping $(\tan \delta)$ modules were determined.

The DSC analyzes were made in the DSC QDSC 2000 - TA Instruments system, with controlled cooling (LNCS). P3HB samples of $2.9 \mathrm{mg}$ was used in a temperature range of -105 to $200{ }^{\circ} \mathrm{C}$, with a heating rate of $10{ }^{\circ} \mathrm{C} / \mathrm{min}$ and a dynamic nitrogen atmosphere of $20 \mathrm{~mL} / \mathrm{min}$. Thermogravimetric analysis (TGA) was performed in a temperature range used in the test was 20 to $850{ }^{\circ} \mathrm{C}$, with a heating rate of $10{ }^{\circ} \mathrm{C} / \mathrm{min}$ and an air flow of $100 \mathrm{~mL} / \mathrm{min}$. Morphology analysis was performed in the fracture region using the Scanning Electron Microscope (SEM) JEOL JSM-6460LV (COPPE / UFRJ) with a voltage of $15 \mathrm{kV}$. The samples were metallized with gold.

Persp. Online: exatas \& eng., Campos dos Goytacazes, 29 (10) $13-29-2020$ 


\section{RESULTS AND DISCUSSION}

Through the micrographs presented in Figure 1, it is possible to observe the spherical morphology of the P3HB/ND encapsulate. Figures 1a, 1b, 1c and 1d show the four formulations of the $\mathrm{P} 3 \mathrm{HB} / \mathrm{ND}$ microcapsules produced, which were used to make the specimens. One of the main differences of the formulations is in the dispersion of the microcapsules, which can generate a better distribution of the ND in the biocomposite matrix.

By figure 1a, referring to the first formulation produced (Sample 1), it is possible to notice that the particles are dispersed from each other, which means that there was no agglomeration of the spherical particles and there was also no coalescence of them. They were morphologically uniform and spherical particles were predominated in sample 1 . In the second formulation produced, sample 2, (Figure 1b) it is possible to visualize some agglomerates and coalescence of $\mathrm{P} 3 \mathrm{HB} / \mathrm{ND}$ microcapsules, in the same sample it is also noticed that some particles appear deformed, no longer in the shape of a perfect sphere, indicated by the red arrows. In figure 1c, these characteristics are becoming more intense. This means that in the encapsulation of the sample 3, greater particle coalescence was generated. The micrograph shows that some particles are no longer spherical and take on stretched shapes.
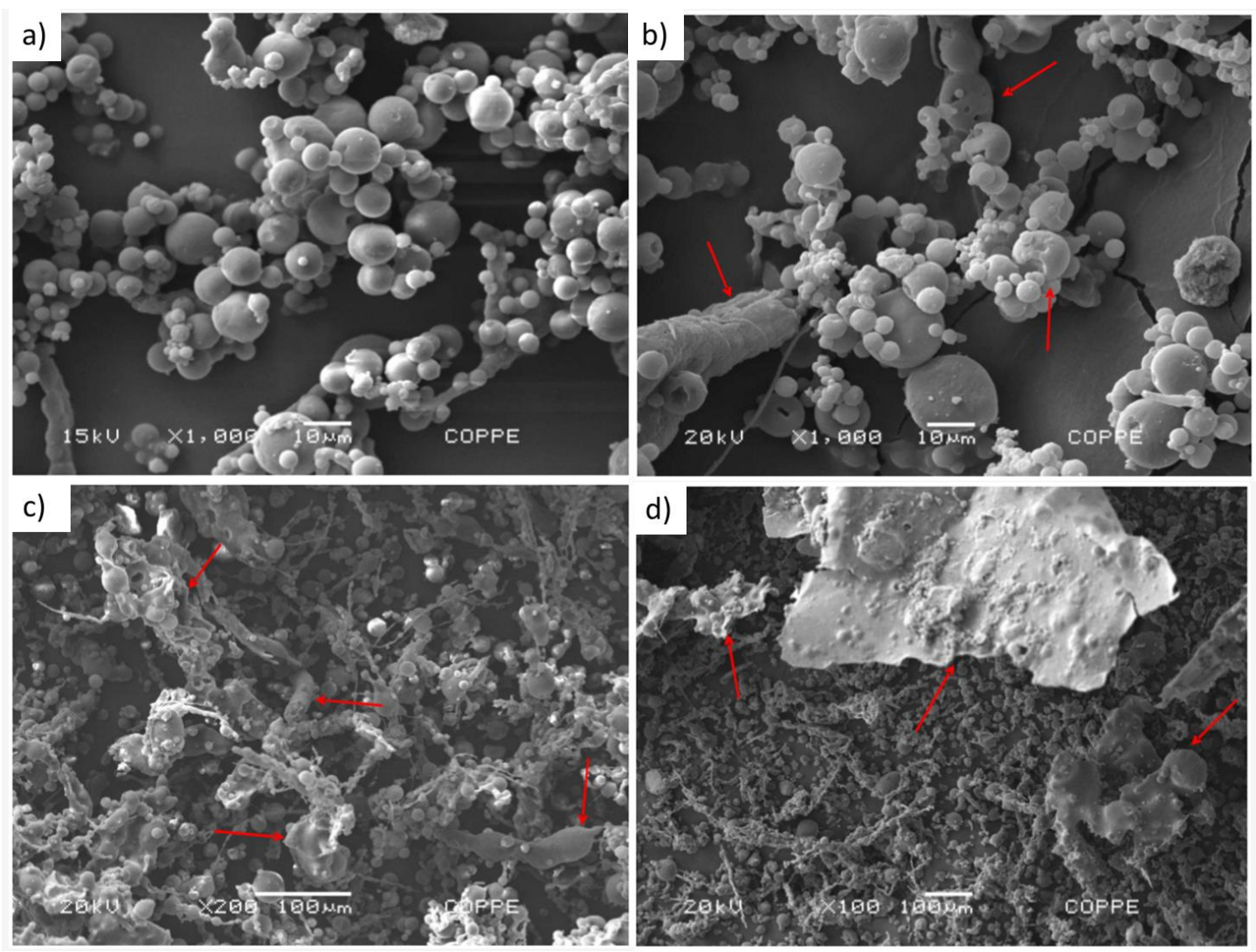

Figure 1: P3HB/ND microcapsules for a) sample 1, b) sample 2, c) sample 3 and d) sample 4. The arrows indicate particles coalescence.

In sample 4 these deformations of the particles continue to occur and the clusters coalesce in greater proportions as can be seen in figure 1d. In this case, the coalescence reached a proportion of film formation of $\mathrm{P} 3 \mathrm{HB} / \mathrm{ND}$. The regular particle morphology has a great influence on the mechanical properties of the final biocomposite, as they generate a

Persp. Online: exatas \& eng., Campos dos Goytacazes, 29 (10) $13-29-2020$

https://ojs3.perspectivasonline.com.br/ 
better distribution of the diamond charge in the P3HB matrix after the specimens are processed. In addition, coalesced agglomerates impair the compaction of particles in the molding process to produce specimens, causing a lack of contact between them.

From the XRD the degree of crystallinity was determined, or as it is often called the crystalline fraction, is a parameter of great importance in the definition of physical and chemical properties of a polymer (COELHO et al.,2008), which makes it necessary to analyze it together with the mechanical properties. In particular, poly (3-hydroxybutyrate), as it is a highly crystalline material, it generally becomes more fragile and has a smaller range of applicability (OLIVEIRA et al., 2007).

Considering the microcapsules of the $\mathrm{P} 3 \mathrm{HB} / \mathrm{ND}$ biocomposites (samples 1-4) it is possible to perceive that the presence of the nanoparticles of ND initially promote an increase in the crystallinity of the polymeric matrix until the sample 3 (14\% of ND), and for the sample 4 there is a downward trend. Jee and Lee (2011), when studying the addition of ND in a thermoplastic matrix, indicates that the effect of adding diamond nanoparticles in a polymeric matrix is to increase the crystalline fraction of the matrix, since the NDs act as a nucleation agent for new crystals causing the matrix is more crystalline, however when the amount of ND particles increases, the effect becomes that of decreasing the crystalline fraction, this trend is associated with the agglomeration of diamonds, which limits the organization of the polymer chains so that they crystallize.

Table 1: Percentage of crystalinity of the sample 1-4

\begin{tabular}{ccccc}
\hline Sample & $\begin{array}{c}\text { Crystallinity }(\%) \text { by } \\
\text { XRD }\end{array}$ & $\Delta \mathbf{H}_{\mathbf{m}}(\mathbf{J} / \mathbf{g})$ & $\mathbf{T}_{\mathbf{m}}\left({ }^{\circ} \mathbf{C}\right)$ & $\begin{array}{c}\text { Crystallinity } \\
(\%) \text { by } \mathbf{D S C}\end{array}$ \\
\hline 1 & 54.8 & 70.90 & 173.1 & 53.25 \\
2 & 55.9 & 71.0 & 171.5 & 55.1 \\
3 & 60.1 & 108.5 & 173.6 & 86.11 \\
4 & 59.0 & 65.68 & 169.9 & 56.02 \\
Neat P3HB & - & 103.5 & 172.5 & 70.90 \\
\hline
\end{tabular}

Through the scanning electron micrographs of figure 2, these clusters of ND can be seen and, consequently, the tendency to decrease the crystallinity of the sample 4 compared to sample 3. The calorimetric analysis of all the sample allowed the calculation of $\Delta \mathrm{H}_{\mathrm{m}}$, which is the heat of fusion associated with the crystalline phase of the matrix and the melting temperature $(\mathrm{Tm})$ of each formulation. These properties are related to crystal architecture (table 1). Samples 1 and 2 have close values of $\Delta \mathrm{H}_{\mathrm{m}}$, melting temperatures and percentages of crystallinity, as can be seen in table 1. Sample 3 obtained higher heat of fusion and temperature of fusion associated with crystalline phase and, consequently, greater crystallinity, agreeing with XRD results, while sample 4 obtained the lowest values of the three properties, presenting less crystallinity and crystals probably with greater defects. These differences may be associated with the amount of ND present in the particles of ND encapsulated by $\mathrm{P} 3 \mathrm{HB}$, as well as the dispersion of ND particles in the polymeric matrix of

Persp. Online: exatas \& eng., Campos dos Goytacazes, 29 (10) $13-29-2020$ 
$\mathrm{P} 3 \mathrm{HB}$, generating or not ND clusters that influence the crystallinity, Tm and $\Delta \mathrm{H}_{\mathrm{m}}$ of the formulations.

Figure 2 shows the flexion modules of the biocomposites for sample 1-4, according to the ND concentrations in the P3HB matrix, 9, 12, 14 and 20\% of ND, respectively, as well as the modulus of the pure $\mathrm{P} 3 \mathrm{HB}$ matrix obtained by the flexion test. It is possible to notice that with the addition of the ND particles the modulus is increased in relation to the pure matrix, for all ND concentrations, whatever the dispersion state of the nanoparticles shown in the micrographs of figure 3 . This effect is due to the high modulus of elasticity of the particulate load of ND. For a better estimation of the effect of the presence of nanocharges in the polymeric matrix $\mathrm{P} 3 \mathrm{HB}$, two classical mechanical models were used as a reference to observe the variation of the biocomposite module. The first was the Voigt-Reuss model (REYNAUD et al., 2001). This model provides a linear relationship between the modules of the composite matrix and the volumetric fraction of the load, roughly estimating the final module of the composite (estimated). Thus, the real modulus of the composite, that is, the experimental values, must be located between two theoretical limits (upper and lower) indicating a good dispersion of the nanocharges in the matrix, that is, it indicates that the composite has a homogeneous load distribution. (FU et al., 2008; REYNAUD et al., 2001; ZHAO et al., 2010).

The experimental values are in between the two limits proposed by Voigt and Reuss, this indicates that there was a homogeneous load distribution throughout the biocomposite. From Figure 2, it is still possible to notice that the higher the concentration of particles of ND the module decreases, mainly for the sample 2 and 4, with 12 and $20 \% \mathrm{ND}$, respectively. This decrease in modulus is associated with the agglomeration of the nanoparticles as there is an increase in the percentage in the biocomposite, these agglomerations can be viewed in the scanning electron micrographs in figure 3. The larger module for sample 1 (9\% ND), in comparison to other samples, can also be explained by the lack of agglomerations in this biocomposite, figure 3 a shows that the ND particles are dispersed and not agglomerated in the matrix, confirming what was predicted by Voigt-Reuss model.

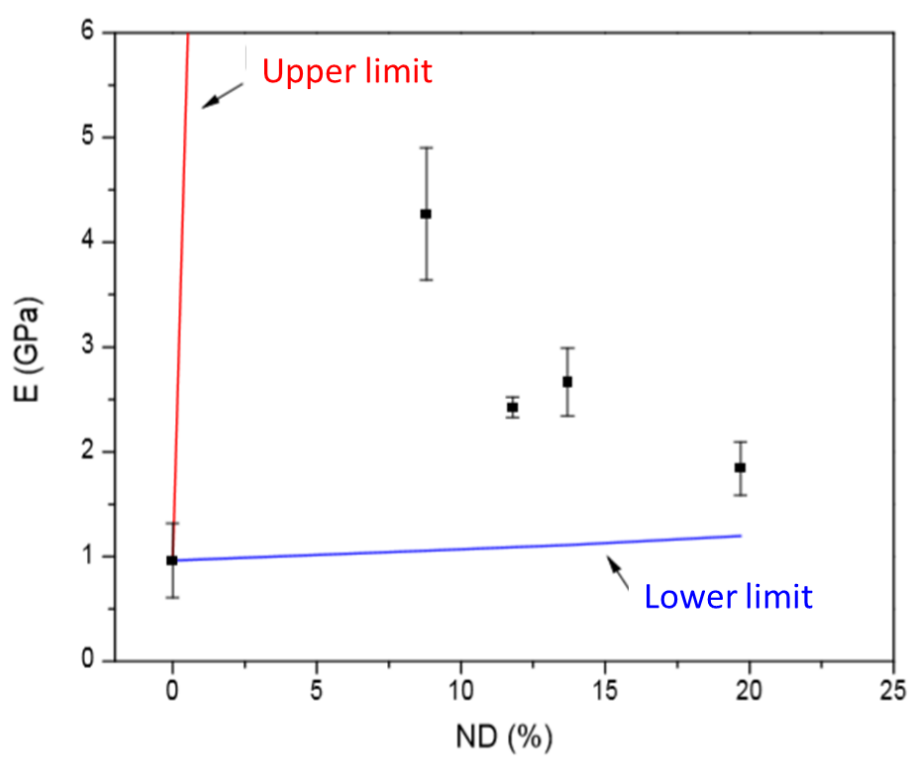

Figure 2: Effect of the concentration of ND in the biocomposites and upper and lower limits predicted by Voigt-Reuss model.

Persp. Online: exatas \& eng., Campos dos Goytacazes, 29 (10) $13-29-2020$ 

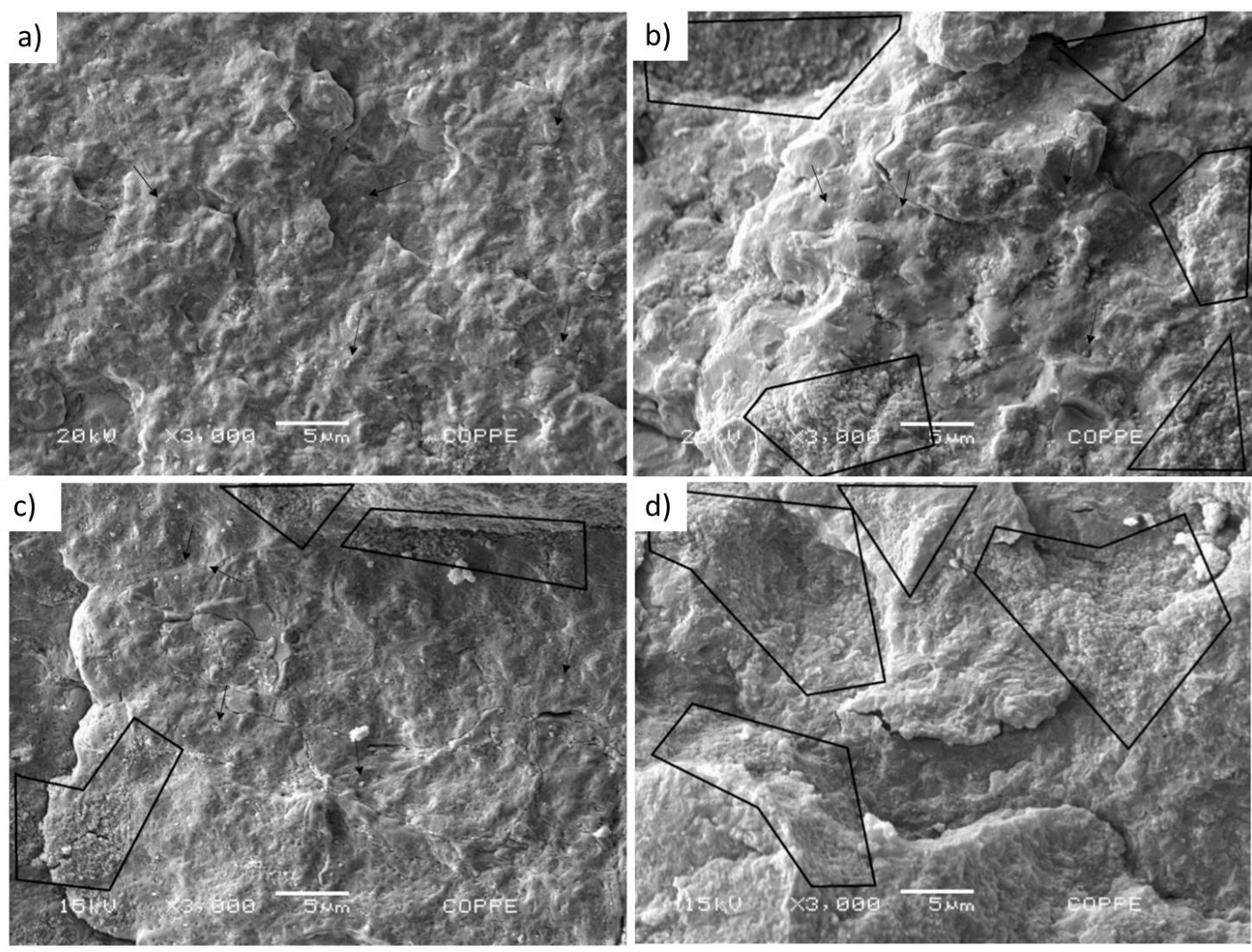

Figure 3: SEM images of the fracture surface of a) sample 1, b) sample 2, c) sample 3 and d) sample 4. The arrows indicate the particles of ND dispersed in the matrix and the black lines indicate the size of the agglomerates.

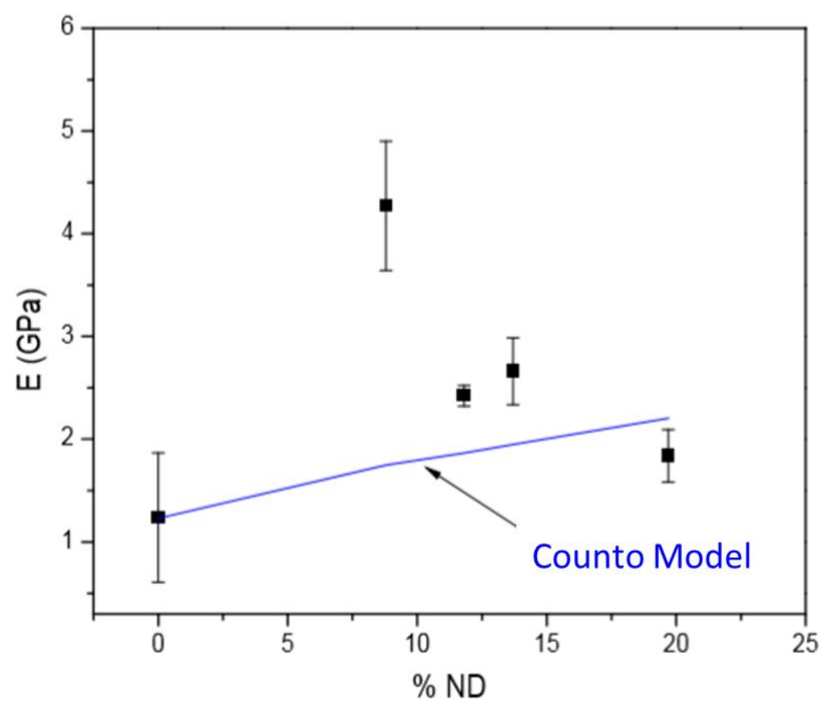

Figure 4: Effect of the concentration of ND in the biocomposites and approximation line predicted by Counto model.

The second model used to evaluate the influence of nanodiamonds on the $\mathrm{P} 3 \mathrm{HB}$ matrix was the Counto model, which assumes that the increase in the module is associated with a good interfacial charge / matrix connection. This model has been widely studied and found that its results are fully in accordance with experimental data (FU et al., 2008). In figure 4 , sample $4(20 \%$ ND) was below the theoretical approach line of the Counto model. This indicates the weak interaction between the load and matrix for this biocomposite, this poor

Persp. Online: exatas \& eng., Campos dos Goytacazes, 29 (10) $13-29-2020$

https://ojs3.perspectivasonline.com.br/ 
adhesion is associated with the agglomeration of NDs. Therefore, with these clusters there is no contact of the matrix with particles of ND inside these clusters causing the module to decrease. Figure 5 shows the great extent of the agglomerates for sample 4 when it is compared to sample 1 (9\% ND), as well as the weak interaction load/matrix adhesion imposed by the agglomeration of nanodiamonds.
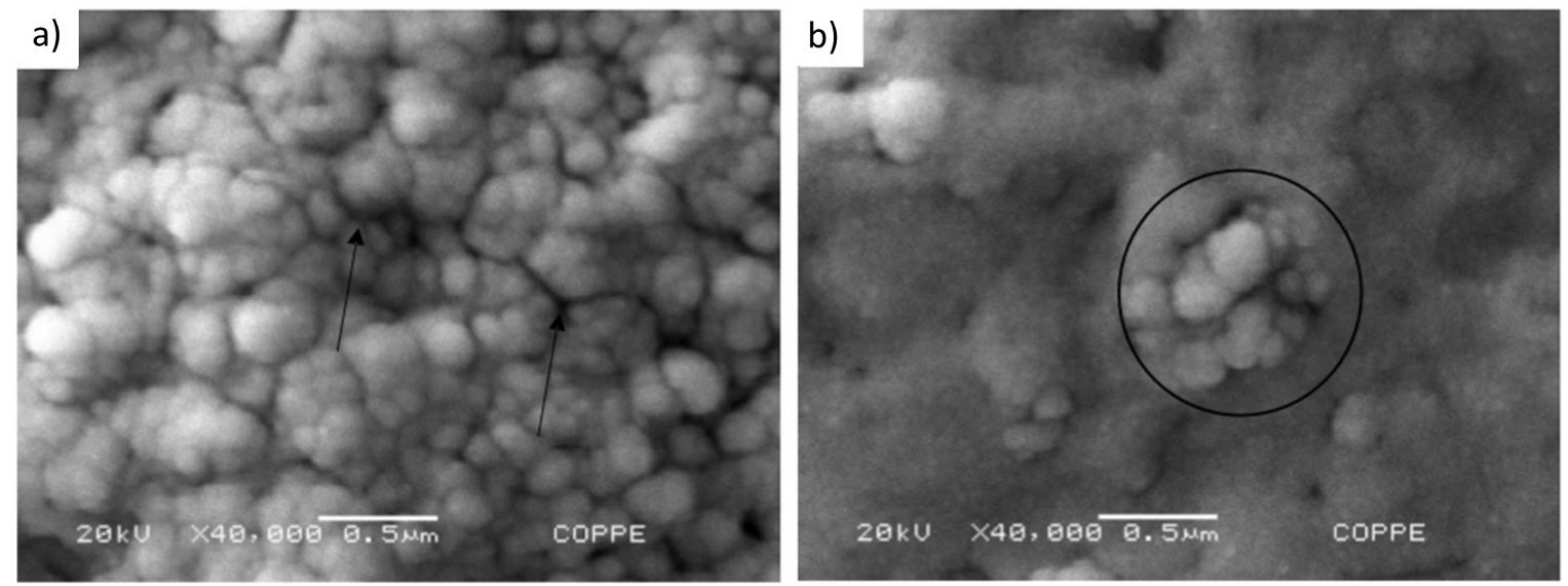

Figure 5: Comparison between the sizes of agglomerates in a) sample 4 and b) sample 1 . The arrows indicate the weak interaction for sample 4 (a) and the circle indicates the size of the agglomerates in sample 1(b).

Nicolais-Narkis model also was used to analyze the load/matrix interaction. This model estimates the load/matrix adhesion by the mechanical strength and it assumes that when there is some reduction in the mechanical strength of the composite, it is due to the weak interaction between the load and the matrix that generates a loss of useful section of the material, this means that as the interface between the two phases is not well adhered one space between them is assumed, causing the useful section of the composite to decrease, also decreasing the final strength, since there will be no transfer of the efforts resulting from the application of loads to the loading phase, which is the phase responsible for reinforcing the material. Thus, the function of preventing the propagation of cracks in the material is lost (FU et al., 2008).

Figure 6 shows the highest value for sample 1 and the lowest for sample 2 and 4 . Since the weak mechanical properties are associated with the agglomeration of the NDs and the weak interaction between the nanodiamonds and the $\mathrm{P} 3 \mathrm{HB}$ matrix figure $3 \mathrm{~d}$ depicts large clusters and crack caused by the lack of adhesion of the clusters to the matrix in sample 2 (XIE et al., 2009) which are not efficient uniform transfer of stress, acting as stress concentrators, propagating these cracks, thus decreasing the strength of the composite (HAN at al.,2011).

Figure 7a shows the load/matrix interface for sample 2. It is possible to see very clearly the weak load/matrix interaction through the empty spaces left by ND particles that were released during the fracture in the mechanical test, this weak adhesion and, consequently, loosening of the nanoparticles promoted small cracks in the matrix indicated with red arrows, that propagate freely through the material, since the load/matrix interface is not efficient to stop them. In contrast, Figure $7 \mathrm{~b}$ shows the good adhesion of the nanodiamonds in the matrix for sample 1 , which due to the smaller amount of ND particles

Persp. Online: exatas \& eng., Campos dos Goytacazes, 29 (10) 13 - 29 - 2020

https://ojs3.perspectivasonline.com.br/ 
did not form agglomerates.

As the effect of nanoparticles on the strength of a composite can be both the increase in values, serving as a reinforcement and crack propagation barrier, as well as the effect of decreasing resistance, when these particles act as stress concentrators. The two effects must be taken into account, as in composite materials they compete with each other (FU et al., 2008). Through the analyzed mechanical models, it is possible to make a correlation of the acquired properties with the particle morphology of the formulations and the fracture surface analysis of the biocomposites. In this way, the sample that most distanced themselves from the approximations of the mechanical models, were those that obtained bad dispersions of the nanofillers and weaker load/matrix interaction.

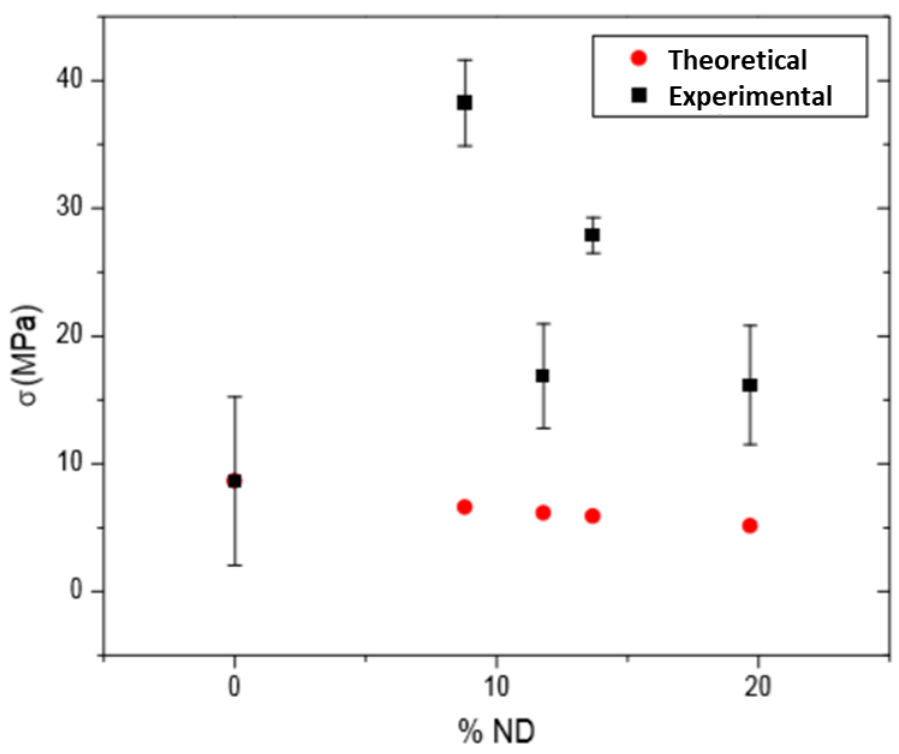

Figure 6: Effect of the concentration of ND in the biocomposites and theoretical values calculated by Nicolais-Narkis model.
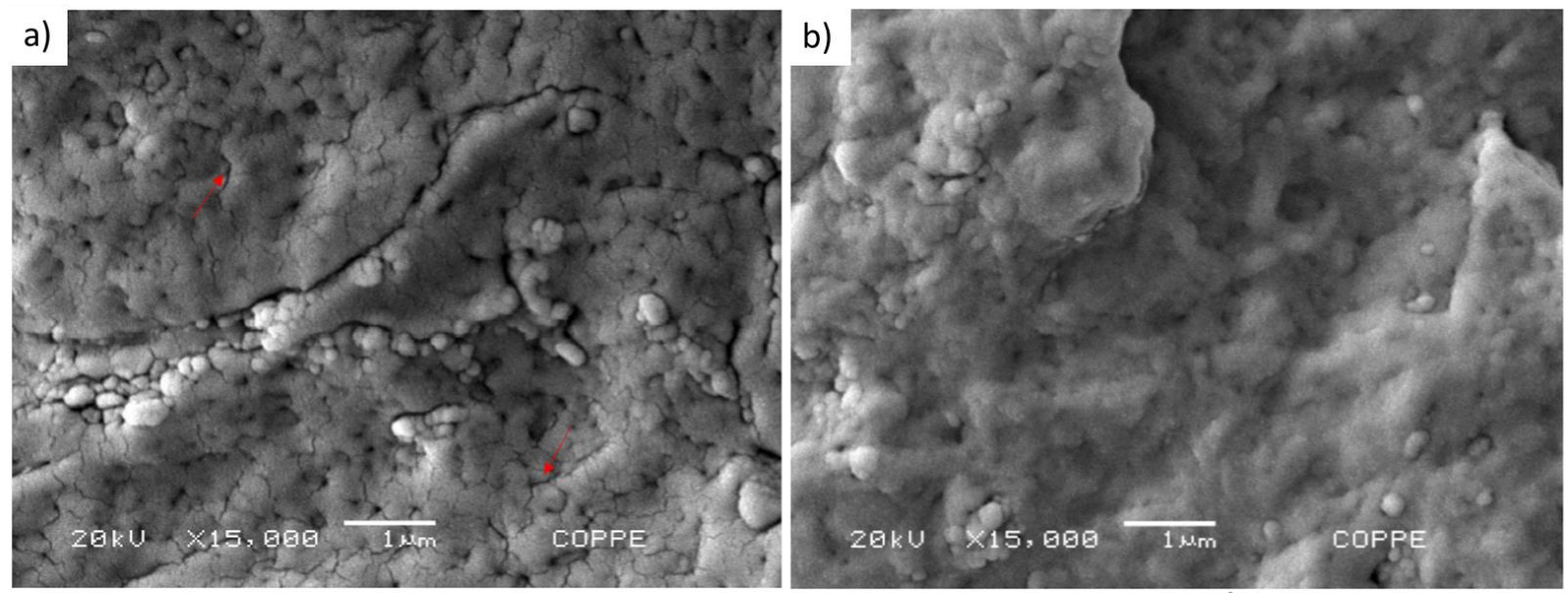

Figure 7: a) Cracks and weak adhesion between ND and P3HB matrix for sample 2, and b) good adhesion for sample 1. The arrows indicate the space left by ND particles for the weak interaction with the matrix.

Compressive tests were carried out in samples 1-4 and table 2 show the values for

Persp. Online: exatas \& eng., Campos dos Goytacazes, 29 (10) $13-29-2020$

https://ojs3.perspectivasonline.com.br/ 
compressive strength and elastic modulus, also the flexural properties are present in the table. Table 2 also shows some of these properties for the cortical and trabecular bones found in the literature (MORGAN at al., 2018; PUPPI et al., 2010).

The DMA analysis was done to understand the viscoelastic behavior of the samples. The curves of the storage module versus temperature are shown in figure 8a. At temperatures close to $25^{\circ} \mathrm{C}$, the reinforcing effect of the nanocharges is observed because of the anchoring of the polymer chains that limits the beginning of their conformational movements (CHEN; WANG, 2002). The sample 1 and 3 obtained the highest values of the module, these samples also presented the best flexural, microhardness and compression properties (BARROS JR, 2014).

Table 2: Compressive and flexure mechanical properties

\begin{tabular}{ccccc}
\hline Sample & $\begin{array}{c}\boldsymbol{\sigma}_{\text {compressive }} \\
(\mathbf{M P a})\end{array}$ & $\begin{array}{c}\mathbf{E}_{\text {compressive }} \\
(\mathbf{G P a})\end{array}$ & $\boldsymbol{\sigma}_{\text {flexure }}(\mathbf{M P a})$ & $\mathbf{E}_{\text {flexure }}(\mathbf{G P a})$ \\
\hline 1 & - & - & $38.21 \pm 3.36$ & $4.27 \pm 0.52$ \\
2 & - & - & $16.82 \pm 4.09$ & $2.42 \pm 0.09$ \\
3 & $71.61 \pm 3.05$ & $163.72 \pm 15.18$ & $27.89 \pm 1.41$ & $2.67 \pm 0.32$ \\
4 & $41.88 \pm 1.93$ & $87.85 \pm 5.29$ & $16.13 \pm 4.65$ & $1.94 \pm 0.256$ \\
Neat P3HB & $36.31 \pm 2.314$ & $74.44 \pm 1.55$ & $7.79 \pm 1.73$ & $1.28 \pm 0.081$ \\
Cortical bone & - & - & - & $5-18$ \\
Trabecular bone & $2-12$ & $50-500$ & 7.7 & $0.02-0.5$ \\
\hline
\end{tabular}

The best dispersion of the sample 1, seen by SEM image, promotes a more efficient anchoring of the chains, in sample 3 , despite the presence of diamond clusters, it is possible to observe in the scanning electron microscopy of figure $3 \mathrm{c}$ that these clusters are small and that there are ND particles dispersed in the matrix, as indicated by arrows in the micrograph. Thus, the effect of limiting the mobility of the polymeric chains is more efficient than for sample 4, which have clusters to a large extent that can be considered as a phase segregation. Thus, sample 4 has basically two regions (figure 3d), one with a large concentration of diamonds (agglomerates) and another formed by the greater volume of the polymeric phase in which the mobility of the chains is not limited.

For sample 2, the main reason for this formulation to have the smallest modulus, compared to other composites, and reaching values close to the value of the neat $\mathrm{P} 3 \mathrm{HB}$ matrix modulus is due to the weak adhesion of the ND with matrix. Figure 7a shows that the NDs are released from the matrix after the flexion test, this lack of adhesion causes the anchoring of the chains to be impaired. By the $\tan \delta$ versus temperature curve $\left({ }^{\circ} \mathrm{C}\right.$ ) (figure $8 \mathrm{~b}$ ) it is possible to notice some variation in the glass transition temperatures for the compositions of composites. Sample 4 has a Tg value similar to the P3HB matrix, due to the causes previously discussed.

Persp. Online: exatas \& eng., Campos dos Goytacazes, 29 (10) $13-29-2020$ 
Sample 1 and 3 obtained similar Tg's as well as storage module, with the highest values in relation to the other formulations. This behavior is due to good dispersion without a marked effect of agglomerations of encapsulates for sample 1. Particularly, in sample 3 the significant presence of the crystalline phase and the good load/matrix interaction, which is confirmed by comparing the Nicolais-Narkis model (figure 6), there is a competition between the contribution of clusters and of the crystalline phase in the anchoring of conformational movements, effecting on Tg temperature. Sample 2 has greater Tg than sample 1, showing the expected effect of the increased amount of ND. However, its storage module is lower than sample 1 due to the weak interaction between the nanoparticles diamond and $\mathrm{P} 3 \mathrm{HB}$ as seen in the SEM images (figure 7), which causes the biocomposite stiffness to decrease.
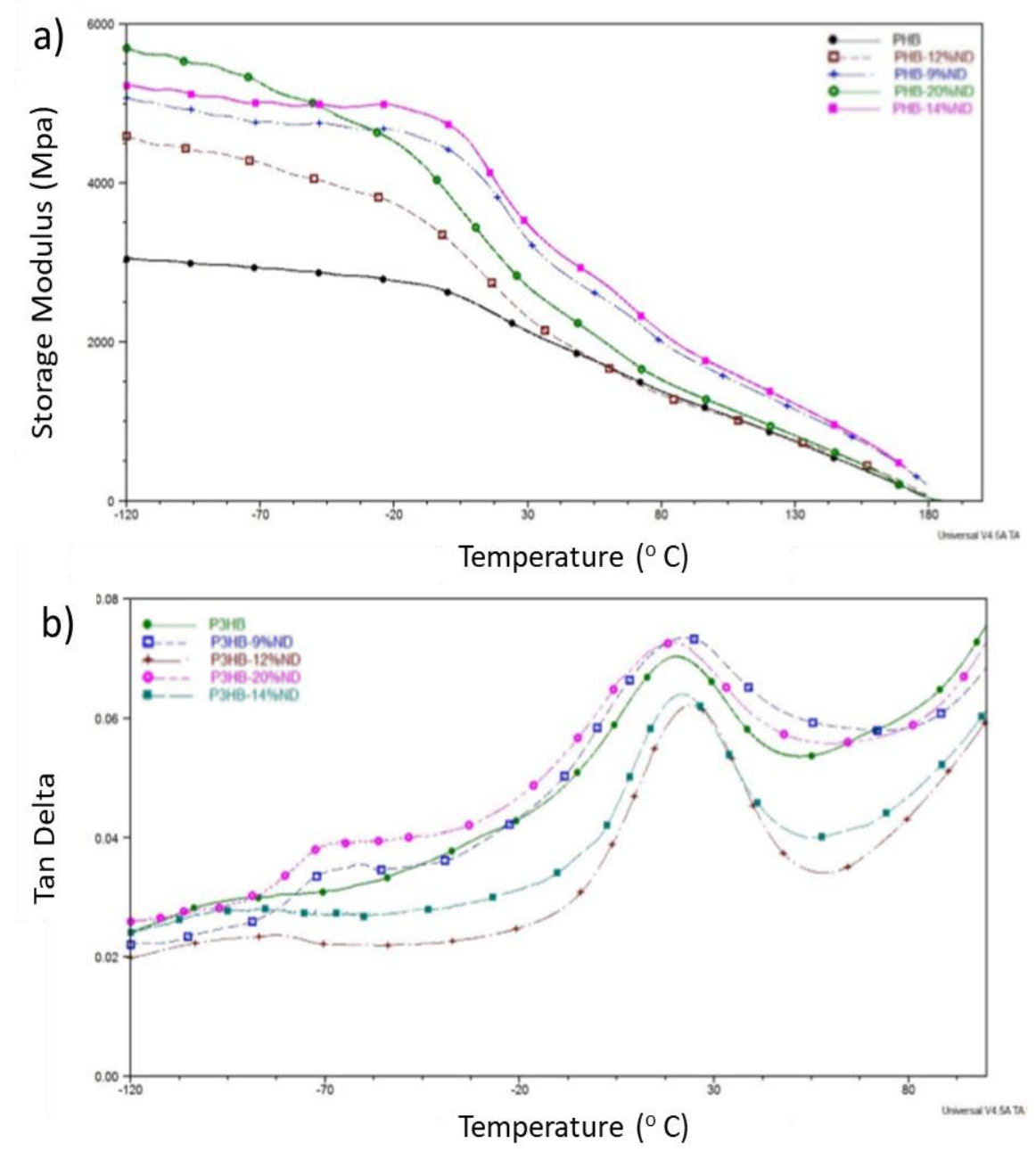

Figure 8: a) Storage modulus and b) Tan Delta versus temperature for samples 1-4.

\section{a. Relationship of mechanical properties to the human bone}

The values of the strength and modulus, flexure and compressive properties for all formulations of the studied biocomposites are shown in table 2. The introduction of nanodiamond particles in the P3HB matrix in the form of microcapsules (figure 1) of NDs coated with the polymer resulted in an increase in mechanical properties in all studied concentrations when compared to the neat P3HB. The flexion modulus in sample 1 was 4.27 $\pm 0.628 \mathrm{GPa}$, which is greater than the same property for trabecular bones ranging in the

Persp. Online: exatas \& eng., Campos dos Goytacazes, 29 (10) $13-29-2020$ 
range of 0.02 to $0.5 \mathrm{GPa}$, and a value that can also be compared with the values of the lower limit for the cortical bone, which according to Morgan ranged from $5 \mathrm{GPa}$ to $18 \mathrm{GPa}$ (MORGAN et al., 2018).

The flexural strength of all biocomposite formulations was higher than that of trabecular bone, which is an average of 7.4 MPa. The compressive properties also obtained values close to the values of the compressive properties of human bone, the compressive module values found for sample 3 was $163.72 \pm 15.22 \mathrm{MPa}$, which is in accordance with the range of compression module of the trabecular bone that varies from 50 to $500 \mathrm{MPa}$. The same occurs for the compressive strength of $71.61 \pm 3.05 \mathrm{MPa}$ for the same sample, the value found exceeds the compressive strength of the trabecular bone, 2 to $12 \mathrm{MPa}$, and reaches a value close to the strength value of the cortical bone that reaches $100 \mathrm{MPa}$ (PUPPI et al., 2010).

These property values very close to the real values of human bone are essential to avoid the incompatibility of rigidity between metallic or ceramic implants on the market with natural tissue, being one of the biggest problems faced in orthopedic surgeries, since during the application of a load in the implant / bone system the amount of load that each component will support is directly related to the stiffness of the material (RAMAKRISHNA et al., 2001). Values of the implant module similar to human bone also prevent bone atrophy, since the bone would thus receive the same load as the implant, without affecting the remodeling and healing process of the bone (ADAMS at al., 1978; CHRISTEL at al., 1991).

\section{CONCLUSIONS}

The implementation of a new methodology, regarding to the coating of nanodiamonds by poly-3-hydroxybutyrate, allowed the encapsulation of the nanoparticles, resulting in spherical geometry capsules, which depending on the percentage $(w / w)$ of ND made it possible to obtain good phase dispersion and relatively narrow size distribution. The surface adhesion of the nanodiamonds with the polymeric matrix, mainly for sample 1, was favored by the preparation methodology as it was properly supported with the aid of the mechanical models Voigt-Reuss, Nicolais-Narkis and Counto. Sample 1 obtained the best mechanical properties, compared to the samples 2, 3 and 4 because of the absence of agglomerates and a better dispersion and distribution of nanoparticles. The values of mechanical properties were compatible with the properties of human bone, both for trabecular $\left(\mathrm{E}_{\text {flexure }}=0.02-0.5 \mathrm{GPa}\right.$, $\left.E_{\text {compressive }}=50-500 \mathrm{MPa}\right)$ and for the cortical $\left(E_{\text {flexural }}=3-30 \mathrm{GPa}\right)$. This, together with the high homogeneity of the material and processability, encourages the continuity of this study for the use of this material in the development of orthopedic devices that can prevent bone atrophy caused by devices on the market with a high module $4.27 \pm 0.628 \mathrm{GPa}$ and $163.72 \pm$ 15.22 Mpa, flexural and compressive, respectively. In Part 2 of the discussion of the biocomposite of $\mathrm{P} 3 \mathrm{HB} / \mathrm{ND}$, its cytotoxicity will be discussed.

\section{ACKOWLEDGMENTS}

The author would like to thank to FAPERJ and CNPQ for financial support, the laboratories and teams of LAMAV/UENF where all the tests were able to be done and COPPE/UFRJ for the SEM image acquisition.

Persp. Online: exatas \& eng., Campos dos Goytacazes, 29 (10) $13-29-2020$ 


\section{REFERENCES}

ADAMS, D.; WILLIAMS, D. F.; HILL, J. Carbon fiber-reinforced carbon as a potential implant material. Journal of biomedical materials research, v. 12, n. 1, p. 35-42, 1978.

ALMEIDA NETO, G. R. de et al. Influence of encapsulated nanodiamond dispersion on P (3HB) biocomposites properties. Materials Research, v. 20, n. 3, p. 768-774, 2017. DOI: 10.1590/1980-5373-mr-2016-0715

AMERICAN SOCIETY FOR TESTING AND MATERIALS. ASTM D695 - 10. Standard Test Method for Compressive Properties of Rigid Plastics. West Conshohocken, 2010 .

AMERICAN SOCIETY FOR TESTING AND MATERIALS. ASTM D790 - 10. Standard Test Methods for Flexural Properties of Unreinforced and Reinforced Plastics and Electrical Insulating Materials. West Conshohocken, 2010.

AMERICAN SOCIETY FOR TESTING AND MATERIALS. ASTM E384 - 11 1. Standard Test Method for Microindentation Hardness of Materials. West Conshohocken, 2011.

BAKAR, M. S. A.; CHEANG, P.; KHOR, K. A. Tensile properties and microstructural analysis of spheroidized hydroxyapatite-poly (etheretherketone) biocomposites. Materials Science and Engineering: A, v. 345, n. 1-2, p. 55-63, 2003. DOI: 10.1016/S0921-5093(02)00289-7

BARCELOS, M. V. et al. Thermo-mechanical properties of P (HB-HV) nanocomposites reinforced by nanodiamonds. Materials Research, v. 20, p. 167-173, 2017. DOI: 10.1590/1980-5373-mr-2017-0077

BARROS JR, L. P. Caracterização térmica, mecânica e in vitro de nanocompõsito de poli(3-hidroxibutirato) (PHB) para aplicações emdispositivos ortopédicos. 2014. 153p. Dissertação (Mestrado) - Universidade Estadual do Norte Fluminense Darcy Ribeiro, Campos dos Goytacazes, Rio de Janeiro, 2014.

CARASCHI, J.; RAMOS, U.; LEÃO, A. Compósitos biodegradáveis de polihidroxibutirato (PHB) reforçado com farinha de madeira: propriedades e degradação. Acta Scientiarum, v. 24, n. 6, p. 1609-1614, 2008. DOI: 10.4025/actascitechnol.v24i0.2475

CHRISTEL, P.; CLAES, L.; BROWN, S. A. Carbon reinforced composites in orthopedic surgery. In: SZYCHER, M. (Ed.) High performance biomaterials: A comprehensive guide to medical and pharmaceutical applications. Technomic, 1991. p. 499-518.

COELHO, M. DE B. Desenvolvimento de metodologia para produção de estruturas tridimensionais porosas de vidro bioativo para aplicação em engenharia de tecidos. 2003. 146 p. Tese (Doutorado) - Escola de Engenharia da UFMG - Universidade Federal de Minas Gerais, Belo Horizonte, 2003.

COELHO, N. S.; ALMEIDA, Y.; VINHAS, G. M. A biodegradabilidade da blenda de poli ( $\beta$-Hidroxibutirato-co-Valerato)/amido anfótero na presença de microrganismos.

Persp. Online: exatas \& eng., Campos dos Goytacazes, 29 (10) $13-29-2020$

https://ojs3.perspectivasonline.com.br/ 
Polímeros, v. 18, n. 3, p. 270-276, 2008. DOI: 10.1590/S0104-14282008000300014

ALMEIDA NETO, G. R. et al. Formulation and characterization of a novel PHBV nanocomposite for bone defect filling and infection treatment. Materials Science and Engineering: C, v. 104, p. 110004, 2019. DOI: 10.1016/j.msec.2019.110004

FARUK, O. et al. Biocomposites reinforced with natural fibers: 2000-2010. Progress in polymer science, v. 37, n. 11, p. 1552-1596, 2012.

FU, S.-Y. et al. Effects of particle size, particle/matrix interface adhesion and particle loading on mechanical properties of particulate-polymer composites. Composites Part B: Engineering, v. 39, n. 6, p. 933-961, set. 2008.

GARCIA, E. E. C. Nanocompósitos: Novas opções em materiais de embalagem. Boletim de tecnologia e desenvolvimento de embalagem, v. 15, n. 1, p. 6, 2003.

HAN, L.; DONG, L. Improving biodegradable polymer nanocomposites. Plastic Research Online, n. c, p. 1-2, 2011.

HOLMES, P. Applications of PHB-a microbially produced biodegradable thermoplastic. Physics in technology, v. 32, 1985. DOI: 10.1088/0305-4624/16/1/305

JEE, A.-Y.; LEE, M. Thermal and mechanical properties of alkyl-functionalized nanodiamond composites. Current Applied Physics, v. 11, n. 5, p. 1183-1187, 2011. DOI: $10.1016 /$ j.cap.2011.02.016

SIQUEIRA, L. C. B. Formulação e caracterização de biomateriais compósitos com hidroxiapatita. 2009. 136 p. Dissertação (Mestrado) - Laboratório de Materiais Avançados - Universidade Estadual do Norte Fluminense Darcy Ribeiro, Campos dos Goytacazes, 2009.

CHEN, L. J.; WANG, M. Production and evaluation of biodegradable composites based on PHB-PHV copolymer. Biomaterials, v. 23, n. 13, p. 2631-2639, 2002.

MORGAN, E. F.; UNNIKRISNAN, G. U.; HUSSEIN, A. I. Bone mechanical properties in healthy and diseased states. Annual review of biomedical engineering, v. 20, p. 119143, 2018. DOI: 10.1146/annurev-bioeng-062117-121139

OLIVEIRA, F. C. et al. Characterization of poly (3-hydroxybutyrate) produced by Cupriavidus necator in solid-state fermentation. Bioresource technology, v. 98, n. 3, p. 633-638, 2007. DOI: 10.1016/j.biortech.2006.02.022

PUPPI, D. et al. Polymeric materials for bone and cartilage repair. Progress in polymer Science, v. 35, n. 4, p. 403-440, 2010. DOI: 10.1016/j.progpolymsci.2010.01.006

RAMAKRISHNA, S. et al. Biomedical applications of polymer-composite materials: a review. Composites science and technology, v. 61, n. 9, p. 1189-1224, 2001. DOI: $10.1016 / \mathrm{S} 0266-3538(00) 00241-4$

REYNAUD, E. et al. Nanofillers in polymeric matrix: a study on silica reinforced PA6.

Persp. Online: exatas \& eng., Campos dos Goytacazes, 29 (10) $13-29-2020$

https://ojs3.perspectivasonline.com.br/ 
Polymer, v. 42, p. 8759-8768, 2001. DOI: 10.1016/S0032-3861(01)00446-3

SATO, M.; WEBSTER, T. J. Nanobiotechnology: implications for the future of nanotechnology in orthopedic applications. Expert review of medical devices, v. 1, n. 1, p. $105-114$, 2004. DOI: 10.1586/17434440.1.1.105

SCHOLZ, M.-S. et al. The use of composite materials in modern orthopaedic medicine and prosthetic devices: A review. Composites Science and Technology, v. 71, n. 16, p. 1791-1803, 2011. DOI: 10.1016/j.compscitech.2011.08.017

SILVA, L. F. DA et al. Produção biotecnológica de poli-hidroxialcanoatos para a geração de polímeros biodegradáveis no Brasil. Química Nova, v. 30, n. 7, p. 1732-1743, 2007. DOI: $10.1590 /$ S0100-40422007000700040

XIE, Y. et al. Poly(3-hydroxybutyrate-co-3-hydroxyhexanoate) nanocomposites with optimal mechanical properties. Polymer, v. 50, n. 19, p. 4656-4670, 2009. DOI: 10.1016/j.polymer.2009.07.023

ZHANG, Q. et al. Fluorescent PLLA-nanodiamond composites for bone tissue engineering. Biomaterials, v. 32, n. 1, p. 87-94, 2011. DOI: 10.1016/j.biomaterials.2010.08.090

ZHAO, Y.-Q. et al. Nanodiamond/poly (lactic acid) nanocomposites: Effect of nanodiamond on structure and properties of poly (lactic acid). Composites Part B: Engineering, v. 41, n. 8, p. 646-653, 2010. DOI: 10.1016/j.compositesb.2010.09.003 